$\stackrel{N / N}{=}$

Global burnals Inc.

औf

\title{
Child Infectious Morbidity in the USSR during the World War II
}

\author{
By Sher S.A., Albitskiy V.Yu. \& Baranov A.A.
}

Abstract- This article presents the results of historical and medical research reflecting infectious morbidity among children during the Second World War (the Great Patriotic War 1941-1945). The research is based on archival and literary sources. The study is relevant because the majority of historical and medical research devoted to the war had been carried out in the Soviet epoch and did not always depict an objective image due to the ideological concepts of that time, which often prohibited the publication of certain information. Inconsiderable in number studies have been conducted on this topic in post-Soviet Russia, yet are selective or localized. A review of a wide range of sources provides an independent perspective on the dramatic situation concerning the significant increase of childhood infections during the war. As a result of systemic control measures carried out by public health services, childhood infections had not become endemic. Despite the rising number of tuberculosis cases, STDs, and malaria in the early years of the war, further spread of the socially significant pathologies was prevented.

Keywords: infectious child morbidity, child tuberculosis morbidity, the second world war (the great patriotic war 1941-1945), children's evacuation.

GJMR-K Classification: NLMC Code: D23

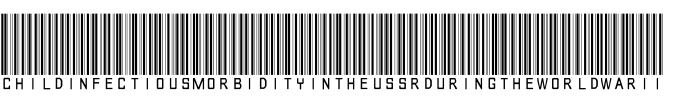

Strictly as per the compliance and regulations of:

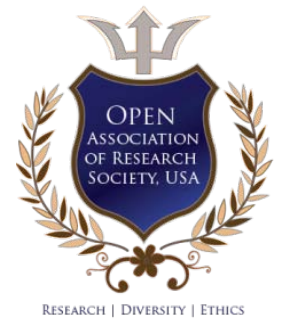

(C) 2020. Sher S.A., Albitskiy V.Yu. \& Baranov A.A.. This is a research/review paper, distributed under the terms of the Creative Commons Attribution-Noncommercial 3.0 Unported License http://creativecommons.org/licenses/by-nc/3.0/), permitting all noncommercial use, distribution, and reproduction in any medium, provided the original work is properly cited. 


\title{
Child Infectious Morbidity in the USSR during the World War II
}

\author{
Sher S.A. ${ }^{\alpha}$, Albitskiy V.Yu. ${ }^{\circ}$ \& Baranov A.A. ${ }^{\rho}$
}

\begin{abstract}
This article presents the results of historical and medical research reflecting infectious morbidity among children during the Second World War (the Great Patriotic War 1941-1945). The research is based on archival and literary sources. The study is relevant because the majority of historical and medical research devoted to the war had been carried out in the Soviet epoch and did not always depict an objective image due to the ideological concepts of that time, which often prohibited the publication of certain information. Inconsiderable in number studies have been conducted on this topic in post-Soviet Russia, yet are selective or localized. A review of a wide range of sources provides an independent perspective on the dramatic situation concerning the significant increase of childhood infections during the war. As a result of systemic control measures carried out by public health services, childhood infections had not become endemic. Despite the rising number of tuberculosis cases, STDs, and malaria in the early years of the war, further spread of the socially significant pathologies was prevented.

Keywords: infectious child morbidity, child tuberculosis morbidity, the second world war (the great patriotic war 1941-1945), children's evacuation.
\end{abstract}

List of abbreviations

TB - tuberculosis

STDs - sexually transmitted diseases or venereal diseases

USSR - Union of Soviet Socialist Republic

RSFSR - Russian Soviet Federated Socialist Republic

SARF - State Archive of the Russian Federation

\section{InTRODUCTION}

$\mathrm{M}$ ay 9, 2020, Russia will celebrate the 75th anniversary of the Victory in the Great Patriotic War, which was integral part of the Second World War. It was the cruelest war in the history of humanity. According to estimates, about 55 million people, 1,800,000 children under 16 years, died during the Second World War. The casualties of the Soviet Union in that war amounted to about 27 million. The most terrible crimes of the Nazis in the occupied Soviet territories were the brutal extermination of children [1].

A drastic deterioration of living conditions of the population, enemy air raids, shelling, prolonged stay in bomb shelters, starvation, death of family members,

Author $\alpha \sigma \rho$ : Research Institute of Pediatrics and Children's Health in Central Clinical Hospital of Russian Academy of Sciences, Moscow, Russian Federation.e-mail: anastel@mail.ru unprecedented migration processes, decrease in the number of pediatricians and nurses due to mobilization to the military service during the Great Patriotic War hurt children's health. The war as an extreme social phenomenon caused an increase in childhood infections and socially significant diseases (STDs and tuberculosis).

The conception of this research was the analysis of situation with the infectious morbidity of children in the USSR during the Second World War. This study is relevant due to two circumstances. First of all, the majority of historical and medical research devoted to the war had been carried out in the Soviet epoch and did not always depict an objective image due to the ideological concepts of that time, which often prohibited the publication of certain information. Secondly, few studies have been carried out on this topic in postSoviet Russia yet are selective or localized.

\section{il. Research Sources}

To describe the condition of children's health, their infectious morbidity during the war, the authors of the given article have studied medical reports, information notices and other documents from the published and unpublished archive materials of the State Archive of the Russian Federation, Archive of the Academy of Medical Sciences of the USSR, regional archives, as well as the research works of pediatric scientists and leaders of Children's Health Care Service, who were contemporaries of the war, and the postSoviet publications.

\section{a) Main results of the research}

Archival materials confirm the enormous damage caused by the German occupants both to the entire national economy of the Soviet Union and to children's institutions. In the occupied territory of the USSR (cities and suburban areas of Smolensk, Voronezh, Kursk, Rostov, North Ossetia republic, the territory of Belarus, Ukraine, etc.) fascist aggressors destroyed all children's hospitals, consultations, nurseries [2]. So, Nazis arranged the first floor of Kursk Central Children's Consultation to stables, the Children's hospital - to hostel for German soldiers, the nursery \# six and Infant-feeding center - to broker's board. When the German army retreated, they had exploded the buildings [3]. Hitler's invaders had destroyed not only children's institutions and their property, as well as killed 
children. M.D. Kovrigina in her book "War and Children" cited some terrifying facts from the indictment documents presented at the International Military Tribunal in Nürberg. So, the Nazis in the resort city of Teberda (North Caucasus) exterminated 500 sick children with bone tuberculosis who were treated in a sanatorium [1]. On Gatchina (Leningrad region), the Nazis "gathered hungry children wandered around the town in a cold stone building, surrounded it with barbed wire, and dozens of little prisoners were dying of hunger every day in this concentration camp" [3].

In such a cruel situation, the incidence of childhood infections increased significantly. The most severe military disasters, extremely unfavorable epidemiological situations affected children who lived in the frontline, occupied territories, and the blockade Leningrad. So, in the Moscow and Leningrad regions, diphtheria morbidity increased due to insufficient coverage of children with anti-diphtheria vaccinations, especially in rural areas, as well as the late hospitalization of diphtheria patients. As a result of this situation mortality from diphtheria increased in some infectious hospitals [4]. Malaria spread widely with the severity of the course of a disease. For example, in occupied Voronezh, 49.4\% of children aged 4 to 12 suffered from malaria during 1943. Infections proceeded against the background of nutritional hypotrophy, anemia [5].

The rapid advance of fascist troops across the territory of the Soviet Union required the organization of an urgent forced evacuation of the population, and, first of all, large children's masses, to the east of the country. By August 1, 1941, 250,000 school-age children had been evacuated from Moscow and Leningrad [6]. In September and October, 60,000 students with teachers from the Moscow boarding schools and 300,000 women with children additionally were evacuated from the capital to the regions of Gorky, Molotov, Chelyabinsk, Novosibirsk, the Tatar, Mordovian, Chuvash, Mari Autonomous Republics and the Kazakh Soviet Republic [7]. By May 1942, 1,648 children's institutions and 188,364 children were removed from Leningrad to the above-mentioned-regions [8]. Before August 15 of the same year, about 25,000 orphans were evacuated [9].

Evacuated inland children had been not in such a dangerous situation, but also they had been in a bind of life conditions. In the first war year, huge nutrition problems (de facto persistent malnutrition), unsatisfactory water supply, and heating dramatically deteriorated the sanitary and epidemiological situation in the evacuation regions. In many areas, evacuated children lived in extremely horiffic living conditions. As a result, pediculosis and scabies spread [6]. These circumstances redounded to widespread childhood infections. For instance, the archival data of the Gorky region, which was a major center for the reception of evacuated people, showed that in October 1941, compared to 1940, the incidence of epidemic typhus and measles was increased respectively in $40 \%$ and $20 \%$. The situation with the dysentery morbidity had deteriorated. If in the pre-war March 1941 in Gorky region 717 patients with dysentery registered, then in September 1941 - 3,658 sick cases [10].

In January 1942, the government adopted a series of legislative and regulatory documents to prevent outbreaks of epidemic diseases. The childhood infections committee was created in the People's Commissariat of Public Health (Ministry for Public Health) of the USSR, which organized anti-epidemic and disinfection teams and sent 175 medical doctors and 350 nurses to work in First aid medical stations, mother and child rooms at railroad stations [11]. In 1942 compared with 1940, the patient capacity of children's hospitals increased by $28 \%$. Moreover, almost half of them were infectious beds. These measure allowed the hospitalization of children with diphtheria and scarlet fever. Specialized units opened for patients with measles and pertussis in some hospitals for the first time [12].

In November 1942 the People's Commissariat of Public Health of the USSR had approved instructional and methodological documents concerning carrying out anti-epidemic work by city children's consultations and polyclinics. This document indicated the necessity to provide a preventive vaccination by children's clinics for outpatients. Particular attention was focused to vaccinate against smallpox. According to this document, pediatricians were due to immediately hospitalizing patients with scarlet fever and diphtheria [13]. March 24, 1944, the People's Commissariat of Public Health of the USSR had approved the "Instruction on the Organization of Isolation Facilities and Quarantine Groups in Kindergartens." On the base of this Instruction, isolation wards were organized in kindergartens to serve patients with mild forms of childhood infections, and quarantine groups were formed for children who had contact with homogeneous disease (measles, pertussis, epidemic parotitis, chickenpox) [14].

Thanks to the measures, pediatricians were able to prevent epidemic diseases and reduce child morbidity. In the first half of 1943, the level of infectious diseases decreased in the Tatar Republic, Penza, Kirov, Gorky regions [15]. In 1943 the morbidity of dysentery and toxic dyspepsia decreased by more than three times. The case rate reduction was connected with mandatory hospitalization of sick children, treatment with sulfa drugs, bacteriophages in children groups [9]. In 1944 the morbidity of diphtheria, scarlet fever, pertussis, and measles continued to decrease (Table 1) [16]. 
Table 1: Incidence of childhood infectious diseases in the Soviet Union (USSR) and Russian Soviet Federative Socialist Republic (RSFSR) during the Great Patriotic War (1:10,000 population)*

\begin{tabular}{|c|c|c|c|c|c|c|c|c|}
\hline \multirow{2}{*}{ Diseases } & \multicolumn{4}{|c|}{ USSR } & \multicolumn{5}{c|}{ RSFSR } \\
\cline { 2 - 9 } & 1940 & 1941 & 1944 & 1940 & 1941 & 1942 & 1943 & 1944 \\
\hline Diphtheria & 9,9 & 10,3 & 8,2 & 11,4 & 13,0 & 16,9 & 13,0 & 7,7 \\
\hline Scarlet fever & 12,6 & 13,6 & 5,0 & - & - & - & - & - \\
\hline Pertussis & 25,7 & 25,7 & 23,1 & - & - & - & - & - \\
\hline Measles & 68,1 & 80,0 & 65,8 & 72,0 & 85,0 & 37,9 & 16,3 & 14,5 \\
\hline
\end{tabular}

*Footnote: In 1941-1942 relative incidence rates were determined only in 39 backlands

According to the table data, the highest level of diphtheria morbidity occurred in 1942 in RSFSR. The increase in the incidence in large cities, as well as in the Moscow region, was explained by a high population density and closer contact between children. Almost $50 \%$ of the cases were children of preschool age. A very noticeable decrease in the incidence of diphtheria began in 1943 and continued steadily during 1944. The maximum prevalence of measles (85 per 10,000 population) were in the second half of 1941 due to the massive evacuation of the children from the western and central regions of the country to the eastern. From 1942 the measles morbidity began to decrease markedly, and in 1943-1944 came down quickly. Measles rate reduction was explained by the uninterrupted supply of anti-measles sera from specialized measles laboratories and research institutes of some backlands [2].

As a result of the carried out anti-epidemic measures, improvement of sanitary conditions of orphanages, boarding schools and regular schools in 1943 in Gorky area the morbidity of measles decreased in 14 times, scarlet fever - in 12 times, dysentery - in 3 times, typhoid - in 2 times, diphtheria - 1,5 times compared to 1940. In 1945 compared to 1940, the morbidity of epidemic typhus was reduced by $72 \%$, dysentery - by $86 \%$, scarlet fever - by $31 \%$ in this area. The child mortality decreased by $23.2 \%$ over the nine months of 1943 compared to 1940 in the Gorky region [10].

During the Great Patriotic war, STDs had been spread, especially in the territory occupied by German troops, where brutal exploitation and violence of the civilian population, including children. On November 3, 1943, the People's Commissariat of Public Health had approved the Instruction for the Prevention of Venereal Diseases in Children's Institutions. According to this Instruction, special rules for admitting children to institutions were established to prevent syphilis. At the slightest suspicion of syphilis, the mother and the child got referrals for a serological test and, if necessary, an X-ray of the limbs. Each child who admitted to orphanage and boarding school had Wasserman's reaction. Sick children with positive Wasserman's reactions were not allowed in children's institutions and referred for antiluetic treatment (archaic Arsenic drug combination of novarsenol, miarsenol, and bioquinol). Children without clinical and serological symptoms but were born from mothers with syphilis were admitted to the nursery only after one combined course of therapy [17].

During the Great Patriotic War, as was always the case during periods of hostilities, when sanitary and hygienic living conditions, nutrition, had been deteriorated, resisting power to disease decreased, the problem of preventing the spread of tuberculosis among both military and civilian populations, including children, became topical issues.

The situation with children's tuberculosis was particularly difficult in Leningrad, where this disease had some features connected with extremely quantitative and qualitative lack of food (children received on food stamp $125 \mathrm{~g}$ of bread in November 1941, $200 \mathrm{~g}$ in December 1941, $400 \mathrm{~g}$ in February 1942). According to pathoanatomical data of one of the Leningrad hospitals, in 1942, the child case fatality rate from tuberculosis compared with 1940 increased almost two times. Most of the sick children had extensive damages to bronchial and mesenteric lymph nodes. Pulmonary TB was diagnosed second in frequency of occurrence, disseminated processes predominated [18].

By the unified methodology of the Central Research Institute of Tuberculosis, a comparative study of tuberculosis-infected patients was tested in Moscow, Gorky, Alma-Ata, and Novosibirsk. This research showed a steady increase amount of tuberculosisinfected among schoolchildren during the war. The proportion of tuberculosis-infected children aged 8-12 increased from $37.7 \%$ in 1940 to $56-61 \%$ in 1944 and adolescents aged $13-17$, respectively, from $56.4-72 \%$ to $64.8-82 \%$. The incidence of tuberculosis among schoolchildren also increased. So, the examination of children in Moscow in 1944 identified that $3.3 \%$ of young schoolchildren and about $4 \%$ of teenagers had pulmonary tuberculosis with $1.5 \%$ of active forms. According to similar examinations, $4.8 \%$ of schoolchildren in Saratov, 6.5\% in the Gorky region, $12.6 \%$ in the Stalingrad region were affected by tuberculosis [19]. The tuberculosis morbidity among schoolchildren was lower in 1944 than in 1942-1943, but higher than the pre-war level [20]. 
From the first months of the war, several normative documents were approved aimed at combating tuberculosis among the children: the directive letter "Measures to preserve the TB network and improvement of TB care to the population" (August 1941); order "Mandatory vaccination of newborn BCG against tuberculosis." On August 8, 1942, the People's Commissar of Public Health of the USSR issued a circular letter on the early detection of tuberculosis in pediatric outpatient clinics and children's hospitals, improving its timely diagnosis. For the review of diagnostic errors, children's consultations and polyclinics should organize joint conferences with TB dispensaries [13].

On July 7, 1943, the People's Commissar of Public Health of the RSFSR prepared a Certificate "Measures to combat tuberculosis." The certificate indicated that the appointments with the TB specialists were resumed in children's consultations, polyclinics, and TB-dispensaries in the Kuibyshev, Kirov, Omsk, the Buryat-Mongol Autonomous Republic and other regions. In some cities (Kalinin, Kuibyshev, Chapaevsk, etc.) for the early diagnosis of tuberculosis, TB doctors conducted screenings of children in nurseries, kindergartens, schools, and, if necessary, gave referral for lung X-ray. Children with identified tuberculosis intoxication were distributed to special sanatory groups in nurseries and kindergartens and students to sanatory "forest schools." All children of early and preschool age had gotten a test of Pirquet's reaction for the detection of tuberculosis in Kuybyshev, Gorky, Chapaevsk, Syzran, Dzerzhinsk, Pavlov, Balakhna, and other cities. Since the end of 1942, newborns vaccination had been activated in urban maternity hospitals. However, often vaccination work was complicated by the viability of vaccines with a limited expiration date. According to the medical report of the People's Commissariat of Public Health of the USSR, vaccination of newborns was carried out by $81.5 \%$ in 1942 , by $87.5 \%$ in the first quarter of 1943 in the Moscow region, by $86.3 \%$ in the Buryat-Mongol Autonomous Republic. But in some regions, in particular, in the Kirov, BCG vaccination was given only by $40 \%$ due to the problem with the vaccine's delivery [21].

On August 2, 1943, the instruction "The struggle against tuberculosis among children at an early age" was approved. To timely detect tuberculosis in young patients, all vaccinated and unvaccinated children had the Pirquet's reaction. Children with a positive Pirquet's result, as well as a negative one, but with suspicion of tuberculosis, were given a Mantoux test. A remarkable point of this instruction was the organization of 1 sanatory groups in nurseries and children's consultations for small patients with chronic tuberculosis, inactive forms of peripheral lymph nodes tuberculosis, residual pleurisy, lymphadenitis in the resorption stage, tuberculosis of the skin and ossicles; 2
- sanatoriums for young children with pulmonary and osteoarticular TB. The city and regional selection committee of experts had carried out the selection of children for TB-resort [17].

The above-mentioned instructions let TBspecialists and pediatricians improve the diagnosis of tuberculosis in the early stages to ensure the isolation of children infected and sick with tuberculosis, their treatment, recovery, and prevention of the spread of the disease.

\section{iil. Conclusion}

Review of a wide range of sources, including documents from the State Archives of the Russian Federation, provides an independent perspective on the dramatic situation concerning the significant increase of childhood infections during the Great Patriotic war both in the occupied territory and in the regions with evacuated children. As a result of the systematic antiepidemic measures carried out by the central and regional health authorities, the epidemics of childhood infections were blocked and did not become a typical phenomenon of wartime. Despite a significant increase of tuberculosis, STDs, and malaria morbidity in the first two years of the war, the further spread of these socially significant diseases were prevented.

Conflict of Interests

Not declared

\section{References Références Referencias}

1. Kovrigina M.D. War and Children. Moscow: Publisher "Home" (In Russian, "Dom"), 1995. 48 p. (In Russ.).

2. State Archive of the Russian Federation (SARF). Fund 8009. People's Commissariat of Public Health of the USSR. Inventory \#21. Case \#66. Report on the condition of Public Children's Health Care during the Great Patriotic War (May 29-December 29, 1944): 23-29. (In Russ.).

3. Manannikova N.V. Medical care service for children in areas of the Russian Federation liberated from German occupation // Writings of the Plenums of the Council of treatment-and-preventive care for children. The Ministry of Public Health of the USSR and the RSFSR. Moscow: Medgiz, 1948: 13-17 (In Russ.).

4. Kovrigina M.D. Medical care for children during the Great Patriotic War // Writings of the Plenums of the Council of treatment-and-preventive care for children. The Ministry of Public Health of the USSR and the Russian Soviet Federated Socialist Republic (RSFSR). Moscow: Medgiz, 1948: 5-13 (In Russ.).

5. Shteinberg L.D. Monitoring the health condition of children in the Voronezh region that was in the occupation zone // Writings of the Plenums of the Council of treatment-and-preventive care for 
children. The Ministry of Public Health of the USSR and the RSFSR. Moscow: Medgiz, 1948: 84-88 (In Russ.).

6. About the children evacuated from Moscow and Leningrad. Resolution of the Organizing Bureau of the Central Committee of the All-Union Communist Party of Bolsheviks from August 22, 1941 // News ["Izvestiya"] of the Central Committee of the Communist Party of Soviet Socialist Republic. Moscow, 1990. September, \# 9: 206-207 (In Russ.).

7. SARF. Fond P-6822. Evacuation Council under the Council of People's Commissars of the USSR. Inventory \#1. Case \#541. Resolutions of the Evacuation Council from \# EC-1 to \# EC-123: 173174 (In Russ).

8. SARF. Fund 2306. People's Commissariat of Education. Inventory 70. Case 2760. Records of control of the Resolution of the Council of People's Commissars of the RSFSR "Measures to Improve the work of evacuated children's institutions" from March 24, 1942 (May 27, 1942-May 1943): 32 (In Russ).

9. SARF. Fund 2306. People's Commissariat of Education. Inventory 70. Case 2782. References, report notes, correspondence of Leningrad District of Education about evacuation and placement of children and schools from Leningrad at the beginning of the school year (March 13-November 11, 1942): 1 (In Russ).

10. Sakovich N.V. Social Problems of Rear area Workers: Health Care Organization in Gorky Region on the Eve and During the Great Patriotic War. Nizhny Novgorod, 2010. - 100 p. (In Russ).

11. Public Health Care during the Great Patriotic War. 1941-1945. Collection of documents and data / Ed. M.I. Barsukov, D.D. Kuvshinsky. Moscow: Medicine, 1977. - 575 p. (In Russ).

12. Goldfeld A.J. Essays on the History of Pediatrics of the USSR. Moscow: Medicine, 1970. - 184 p. (In Russ).

13. SARF. Fund 8009. People's Commissariat of Public Health of the USSR. Inventory \#21. Case \#21. Instructions and circular letters of the Department of Children's Therapeutic and Preventive Institutions of the People's Commissariat of Public Health of the USSR for 1942 (August 8 - November 14, 1942): 22 23 (In Russ).

14. SARF. Fund 8009. People's Commissariat of Public Health of the USSR. Inventory \#21. Case \#155. Data on the issue of medical health care of kindergartens. (January 15-December 20, 1945): 45-46 (In Russ).

15. SARF. Fund 8009. People's Commissariat of Public Health of the USSR. Inventory \# 21. Case \# 61. Data on the condition of evacuated children's institutions (staff report, briefing notes, correspondence). (January 1 - December 25, 1943): 11, $94-95$ (In Russ).

16. SARF. Fund 8009. People's Commissariat of Public Health of the USSR. Inventory \# 21. Case \# 219. Brief report on the activities of the Department of Therapeutic and Preventive Care for Children of the People's Commissariat of Public Health of the USSR and local administration of Therapeutic and Preventive care of children, and the condition of children's health care service during the Great Patriotic War. (November 4, 1947): 1-23 (In Russ).

17. SARF. Fund 8009. People's Commissariat of Public Health of the USSR. Inventory \# 21. Case \# 43. Instructions of the National Commissariat of Public Health of the USSR on issues of child health care (June 7-August 3, 1943): 8-9, 13-15 (In Russ).

18. Myasoedova V.M. Tuberculosis in children in 1942 from the materials of the hospital named after Krupskaya in Leningrad // Issues of pediatrics in the days of the Blockaded Leningrad. Nutritional dystrophy and avitaminosis in children. Leningrad: Medgiz, 1944: 111-114 (In Russ).

19. SARF. Fund 8009. People's Commissariat of Public Health of the USSR. Inventory \# 21. Case \# 145. Data representative of the development of children's health care in the USSR (22 March-22 October 1945). L. 34-40 (In Russ).

20. Kalugina M. N., Brotskaya S.M., Zborovskaya F.I. Physical development and health condition of schoolchildren of Krasnogvardeyskiy district of Moscow in 1944 // Information collection of the Institute of Pediatrics of the Academy of Medical Sciences of the USSR. Moscow, 1946. - P. 53-54 (In Russ.).

21. SARF. Fund 8009. People's Commissariat of Public Health of the USSR. Inventory \# 21. Case \# 41. Data on the struggle against tuberculosis among children (transcript of the session of the Committee on Children's Tuberculosis in the People's Commissariat of Public Health of the USSR from October 20, 1943; protocol of the meeting with Deputy People's Commissar of Health of the USSR Kovrigina M.D. from October 11, 1943) (June 6November 15, 1943): 57 (In Russ.). 